\title{
Embodiment of Early Psychosocial Adversity and Allostatic Load Using a Life Course Perspective: A Review
}

\section{Incorporación de la Adversidad Psicosocial Precoz y la Carga Alostática Utilizando una Perspectiva Biográfica: Revisión de la Literatura}

\author{
Cristina Barboza Solís DDS, MSc. ${ }^{1,2}$ \\ 1. INSERM, UMR1027, Toulouse F-31000, France, \\ 2. Université Toulouse III Paul-Sabatier, UMR1027, Toulouse F-31000+, France, \\ Correspondence to: Dra. Cristina Barboza Solís - cristina.barboza-solis@inserm.fr \\ Received: 3-VII-2015 \\ Accepted: $10-\mathrm{VII}-2015$
}

\begin{abstract}
The role of early life experiences on health is a major concern for research and public health interventions. Recent studies show that being exposed to chronic psychosocial stress during sensitive periods of development can have an impact on later health. It appears that children exposed to adverse conditions (economic, material and psychosocial) show a higher risk of adopting deleterious health behaviors (smoking, alcohol), heightened vulnerability to chronic diseases and mortality. Allostatic load (AL) is a measure of overall physiological wear-and-tear that can be the consequence of early life exposures. AL could allow for a better understanding of the potential biological pathways linking adverse exposures and later health. Here we review current evidence to discuss a biological embedding hypothesis, focusing on adverse psychosocial exposures during childhood and its effects on later AL, taking a life course perspective. Via a non-systematic review of recent literature, we examine whether adverse childhood experiences (ACE), causing chronic stress responses, may alter physiological functioning, as measured by AL. A better understanding of the biological mechanisms underlying psychosocial exposures could contribute to the development of more adapted public health interventions, both at a societal and individual level.
\end{abstract}

\section{KEYWORDS}

allostatic load, adverse childhood experiences, biological embedding, health behaviors, cohort study 


\section{RESUMEN}

El rol de las experiencias vividas durante la infancia sobre la salud genera gran interés y preocupación tanto a nivel de la investigación en salud como a nivel de las posibles intervenciones en salud pública. Estudios recientes muestran que haber estado expuesto al estrés psicosocial durante periodos sensibles del desarrollo podría impactar la salud a largo plazo. Ha sido sugerido que los niños(as) expuestos(as) a situaciones de adversidad (económica, material y psicosocial) muestran un mayor riesgo de adoptar comportamientos riesgosos (tabaco y alcohol), aumentando su vulnerabilidad a las patologías crónicas, acrecentando la mortalidad. La carga alostática (AL por sus siglas en inglés) representa el desgaste fisiológico global que podría ser la resultante de experiencias adversas vividas durante la infancia. La carga alostática podría permitir una mejor comprensión de los mecanismos biológicos implicados que relacionan el estrés psicosocial durante la infancia y la salud del adulto. En este artículo revisamos evidencia actual para discutir una hipótesis de incorporación biológica, centrándose en las exposiciones psicosociales adversas de la infancia y sus efectos sobre la carga alostática del adulto, tomando una perspectiva biográfica (a lo largo de la vida). Via una revisión no sistemática de la literatura reciente sobre el tema, examinamos si las experiencias adversas durante la infancia (ACE por sus siglas en inglés), causando respuestas al estrés crónico, son susceptibles de alterar el estado fisiológico global, medido por la carga alostática. Una mejor comprensión de los mecanismos biológicos subyacentes a las exposiciones psicosociales precoces podría contribuir al desarrollo de intervenciones en salud pública más adaptadas, tanto a nivel colectivo como individual.

\section{PALABRAS CLAVES}

carga alostática, experiencias adversas durante la infancia, incorporación biológica, comportamientos de riesgo, estudio de cohorte

\section{INTRODUCTION}

Nancy Krieger described embodiment as "how we, like any living organism, literally incorporate, biologically, the world in which we live, including our societal and ecological circumstances" (Krieger, 2005). The notion of embodiment proposes that every human being is both a social and a biological organism that incorporates the world in which (s)he grows. The notion of embodiment or biological embedding (Hertzman, 1999, 2012) is a key concept within life course epidemiology; an interdisciplinary framework that analyses long-term biological, behavioral, and psychosocial processes linking early life exposures to health in later life via a number of mechanisms and processes (Kuh, BenShlomo, Lynch, Hallqvist, \& Power, 2003; Kuh, Ben-Shlomo, \& Susser, 2004).
A growing literature shows the early life biological and social determinants of heart disease, diabetes, obesity, depression, premature mortality, among others (Hertzman \& Boyce, 2010). In the early 1990s, Barker showed that exposure to undernutrition in utero was associated with developing coronary heart disease in adulthood (Barker, 2002). These findings opened an extensive field of research studying the early life origins of adult disease (Barker, 2002, 2007) recently known as Developmental Origins of Health and Disease (DOHaD). Since, other factors besides the intrauterine environment have been studied. Felitti et al. conducted in the late 1990s the "Adverse Childhood Experiences (ACE) study" showing that being exposed to psychosocial adversity during childhood -like child abuse, emotional and physical neglect- was strongly correlated with adult risky behaviors, cancer, and early mortality (Felitti, 2002; Felitti et al., 1998). 
Evidence suggests that early psychosocial adversity could have an adverse effect on mental and physical health and appears to be associated with increased activation in the nervous, endocrine, and immune systems (Kelly-Irving, Mabile, Grosclaude, Lang, \& Delpierre, 2013; Li, Power, Kelly, Kirschbaum, \& Hertzman, 2007). Lupien et al. has shown the neurodevelopmental consequences of growing-up in poverty and adversity (Boyce, Sokolowski, \& Robinson, 2012; Lupien, McEwen, Gunnar, \& Heim, 2009). During childhood and adolescence, nervous, endocrine, and immune systems are not fully developed and show significant changes (Danese \& McEwen, 2012). The identification of these mechanisms and their importance for brain and behavioral development starting early in life, support the hypothesis that exposure to chronic psychosocial stress, and its subsequent physiological reaction, can have enduring effects on health throughout the life span (Kelly-Irving, Mabile, et al., 2013).

In the last two decades, epidemiological research has used the concept of allostatic load (AL) to explain how chronic stress can lead to physiological dysregulation and disease (Beckie, 2012; Juster, McEwen, \& Lupien, 2010; McEwen, 2006; Seeman, McEwen, Rowe, \& Singer, 2001; Seeman, Singer, Rowe, Horwitz, \& McEwen, 1997) . AL is a measure of overall physiological wearand-tear over the life course, which could be the consequence of early life exposures (Danese \& McEwen, 2012; Taylor, Way, \& Seeman, 2011). According to AL theory, cumulative and repeated activation of compensatory physiological mechanism in response to chronic stress can lead to a multisystem predisease state represented by a dysregulation of neuroendocrine, metabolic, inflammatory, or cardiovascular parameters (McEwen, 1998; McEwen \& Seeman, 1999). Current research exploring the link between socioeconomic exposures and later health is not consistent and the mechanisms by which psychosocial adversity "gets under the skin" and impact physiological pathways leading to disease remains unclear. The aim of this study is to discuss current evidence of how early psychosocial environment becomes biologically embedded and produces health differences across populations. The hypothesis discussed in this review is that allostatic load may be a suitable indicator of the physiological wear-and-tear produced by embodiment processes over the life course.

\section{CHRONIC STRESS \& EARLY PSYCHOSOCIAL ENVIRONMENT}

Here we utilize an integrative approach that define stress "as a process that entails a stimuli, appraisal of it, and a response" (Miller, Chen, \& Parker, 2011). When an stimuli (better known as stressor) is evaluated as an unmanageable threat, triggers a cascade of behavioural and biological adjustments called responses (Miller, et al., 2011). In this review we focus on chronic psychosocial stress during childhood and its contribution to adulthood health. Chronic stress refers to "an experience where the stimuli remains present in a child's life over a lengthy period of time" (Miller, et al., 2011). Maltreatment, nutritional and material deprivation, socioeconomic and financial disadvantage are examples of stressors that could linger over the lifespan. The National Scientific Council on the Developing Child has proposed three different types of stress responses in children: positive, tolerable, and toxic (Center on the Developing Child Harvard University). The classification was built on the basis of their potential long term physiological damage. "Positive stress" is brief and moderate. It can be socially buffered and represent an opportunity to adapt to adverse situations. "Tolerable stress" produces temporary and potentially damaging stress responses that can be reversible and buffered in a supportive and secure social environment. "Toxic stress" is characterized by the constant activation of the stress response systems -like the hypothalamicpituitary-adrenal (HPA) axis- due to chronic or traumatic experiences in the absence of consistent 
social support, especially during childhood and adolescence (Shonkoff, Garner, Comm Psychosocial Aspects Child, Comm Early Childhood Adoption, \& Sect Dev Behav, 2012). According to the Center on Developing Child "the extent to which stressful events have lasting adverse effects is determined in part by the individual's biological response (mediated by both genetic predispositions and the availability of supportive relationships that help moderate the stress response), and in part by the duration, intensity, timing, and context of the stressful experience" (Center on the Developing Child Harvard University).

Children can be exposed to a wide range of chronic stressors, nevertheless, recent literature showed the importance of psychosocial stress and their consequences on later health, specifically through the stress systems (Danese \& McEwen, 2012; Danese \& Tan, 2014). Psychosocial is defined here as "the interaction between people and their social environment involving psychological processes" (Egan, Tannahill, Petticrew, \& Thomas, 2008) or "pertaining to the influence of social factors on an individual's mind or behavior, and to the interrelation between of behavioral and social factors"(Oxford English Dictionary). In this context the Adverse Childhood Study (ACE study) examined in the 1990s a variety of psychosocial stressors and their impact on health. The authors proposed that exposure to maltreatment, child abuse, physical and emotional neglect can produce toxic stress responses and, in a long term, impact adult health. It is known that the prefrontal cortex, the amygdala, and the hippocampus are regions in the brain particularly sensitive to psychosocial stress (McEwen, 2007). For instance, it has been showed that maltreated children present chronic activation of the HPA axis, blunted cortisol and neuroendocrine responses in specific laboratory tasks.

These findings suggest that an organism is capable of "programming" itself and adapting its biology to face environmental challenges, which make the embodiment of early psychosocial experiences plausible. Nevertheless, interesting methodological and theoretical questions are raised. How does childhood adversity "get under the skin" to become biological and how can we study processes of embodiment occurring throughout life?

ACE EMBODIMENT \& LIFE COURSE PERSPECTIVE: SENSITIVE PERIODS, ACCUMULATION AND PATHWAYS MODELS

The lifecourse approach is a conceptual framework well adapted for studying embodiment, a process occurring over the lifespan. Three lifecourse models have been suggested in biological and medical research. The first is the "biological programming" or sensitive/critical periods model, the second is the accumulation model, and the third is the pathways model (Blane, Netuveli, \& Stone, 2007).

The critical/sensitive periods model suggests that during a phase of development, a biological system is more sensitive to environmental exposures and to deviations from expected experiences -particularly in-utero and early life- and have lasting effects on physiological functioning (Bruer, 2001). Hubel and Wiesel's experiments in the 1960s showed that kittens deprived of visual experience in one eye for 6 weeks after birth remained permanently blind of the deprived eye (Wiesel \& Hubel, 1963). A critical period was therefore identified for the visual system: the brain expects to be exposed to a visual input during a window of development, when the experience does not occur, the system is permanently and irreversibly damaged. Barker et al. showed that prenatal growth predicted coronary heart diseases in adulthood. They suggested that poor nutrition or impairment during foetal development could affect permanently physiological systems and structures leading to chronic diseases (Barker, 2002). This hypothesis has been enlarged to include the 
social environment, identifying important social transitions during human development (Blane, et al., 2007). A sensitive period refers to a longer moment in human development when a given experience will have important effects on the system in question during an specific timing, still allowing the system to adapt to later experiences and reverse or modify the effect (Bailey, Bruer, Symons, \& Lichtman, 2001). The vast literature on critical/sensitive periods suggests the existence of a sensitive period for humans from gestation to three years after birth (Bailey, et al., 2001). Critical/sensitive periods have been suggested for a first and a second language acquisition, as well as for the fundamental basis for social and emotional development (Bailey, et al., 2001). It appear that for higher brain functions and socio-emotional behavior the window of vulnerability may be longer, since the systems involved are more complex (Kelly-Irving, Mabile, et al., 2013). A key socio-emotional process in human development is attachment, or the establishment of a parentinfant bond at birth, that involves a sensitive period. An infant seems to need, for his/her emotional development an, initial attachment relation with a consistent caregiver and a quality relationship of security. Attachment is important for human beings principally because having a caregiver provides protection, assistance and support. It is also important for the development of psychosocial and psychological processes and contributes to stress management buffering the secretion of stress hormones (Gunnar, Brodersen, Nachmias, Buss, \& Rigatuso, 1996). Concerning ACE, the existence of a sensitive period may be plausible. Being exposed to trauma, maltreatment and physical neglect during childhood and adolescence can alter the individual's physiological responses making them vulnerable to subsequent exposures and disease (Bailey, et al., 2001; Kelly-Irving, Lepage, Dedieu, Bartley, et al., 2013; Kelly-Irving, Mabile, et al., 2013).

The accumulation model purposes that longterm exposures across the life course accumulate and have consequences on health. Concerning the study of the link between low socioeconomic position and non-communicable diseases, the accumulation model is the most used model in empirical research (Gustafsson et al., 2014). Lifecourse accumulation of socioeconomic disadvantage appears to cause cumulative damage to biological systems (Gustafsson, et al., 2014). Galobardes et al. highlighted the accumulation processes concerning childhood socioeconomic circumstances. Children from low socioeconomic status could present lower birth weight, have poorer diets, being exposed to passive smoking, infectious diseases and so on (Galobardes, Lynch, \& Smith, 2004). There is a lack of research exploring ACE and the mechanisms of accumulation, however, when analysing the gradual accumulation of physiological dysregulation over the life course, the accumulation model seems appropriate (Seeman, Epel, Gruenewald, Karlamangla, \& McEwen, 2010).

The pathways model arose from the study of health inequalities, characterized by a "finegrained" gradient producing health differences on morbidity and mortality according to social class. Blane et al. posits that "the social structure was suggested as the mechanism that could produce this fine-grained distribution of mortality, by structuring exposure to a range of non-behavioral hazards, which are clustered cross-sectionally and accumulated longitudinally via advantage or disadvantage in the various spheres of life" (Blane, 1995; Blane, et al., 2007). This "chain of risk" model explains how an exposure will lead to another and impact function and increasing disease risk (Kuh, et al., 2004). Typically, the ACE study has shown that being exposed to psychosocial stress early in life, increases the odds of adopting risky behaviors, which in turns promotes the appearance of non-communicable diseases and early mortality (Shanta R. Dube et al., 2006; Felitti, 2002; Felitti, et al., 1998; Ford et al., 2011).

These three lifecourse models are intertwined, influence each other, are not mutually 
exclusive and may operate simultaneously (Kuh, et al., 2004). Life course approach allows to capture the sequence of social risk, psychosocial and material exposures, biological challenges and inferior living conditions across the life course that could damage adult health (Koffijberg, Adami, Buskens, \& Palme, 2012; Kuh, et al., 2004; Power \& Hertzman, 1997).

Some challenges persist when studying ACE in a life course perspective to test the embodiment hypothesis. A first challenge involves ACE, the definition is complex, variable, there are non-linear relation with health, and it can captures other domains besides the psychosocial. The second remaining question is how to conceptualize a measure of embodiment. Should we focus on specific health outcomes, individual biomarkers with clinical thresholds? In this context McEwen et al. proposed the concept of allostatic load $(A L)$, a measure of overall physiological wear-and-tear over the life course that may be the consequence of early psychosocial exposures. A notion that could capture the cumulative physiological burden on the body caused by stressful environmental challenges (McEwen \& Wingfield, 2003).

ADVERSE CHILDHOOD EXPERIENCES (ACE) \& PHYSIOLOGICAL WEAR-AND-TEAR AS MEASURED BY ALLOSTATIC LOAD (AL)

Empirical evidence shows that allostatic load (AL) has strong correlations with subclinical conditions, morbidity, and mortality, and may be a useful measure of overall health, rather than considering each biomarker separately. The notion of $\mathrm{AL}$ may be useful to explore how psychosocial adverse experiences over the life course may become biologically embedded.

The first operationalization of an $A L$ index was conceived by Seeman et al. in 1997 utilizing the MacArthur study of successful aging, a longitudinal study of 70 to 79-year-olds follow-up over 12 years. This $A L$ index included 10 biomarkers of multisystem physiological dysregulation: DHEA-S, urinary free cortisol, epinephrine, norepinephrine, systolic blood pressure, diastolic blood pressure, waist-hip ratio, high-density lipoprotein cholesterol (HDL-C), the ratio of total cholesterol to HDL-C (TC/HDL-C) and glycosylated hemoglobin. Each biomarker was then dichotomized into high risk versus low risk according to sex-specific quartiles. The high-risk quartile was the top quartile of all biomarkers, except for those for which a low level confers greater risk for poor health outcomes (e.g. HDL-C) (Seeman, et al., 2001; Seeman, et al., 1997). This index of AL was a better predictor of mortality and physical functioning relatively to metabolic syndrome (Karlamangla, Singer, McEwen, Rowe, \& Seeman, 2002; Karlamangla, Singer, \& Seeman, 2006), and may be a useful measure of overall health, rather than considering each biomarker separately (Beckie, 2012; Carlson \& Chamberlain, 2005).

In the last decade, researchers have explored the link between early childhood/adolescence and later AL (Barboza Solis et al., 2015; Robertson, Benzeval, Whitley, \& Popham, 2015). Three main pathways have been put forward: (i) an indirect health behaviors pathway, (ii) an indirect socioeconomic/materialist and/or psychosocial pathway, (iii) through a direct biological pathway via early alterations of physiological stress systems (e.g., hypothalamic-pituitary-adrenal axis). In a recent study we showed that exposure to Adverse Childhood Experiences (ACE) can alter $\mathrm{AL}$ at 44 years, after taking birth and childhood factors into account (Barboza Solis, et al., 2015). We utilize the National Child Development Study, a British birth cohort $(n=18000)$ followed-up since 1958 (Power \& Elliott, 2006). The AL index was conceptualize using 14 biomarkers representing four physiological systems: the neuroendocrine [salivary cortisol t1, salivary cortisol t1-t2]; the immune/inflammatory [insulin-like growth factor-1, C-reactive protein, fibrinogen, IgE]; the metabolic system [HDL, LDL, triglycerides, glycosylated 
hemoglobin]; the cardiovascular and respiratory systems: [systolic blood pressure, diastolic blood pressure, heart rate/pulse, peak expiratory flow] (Barboza Solis, et al., 2015). ACE were defined as a set of traumatic and stressful psychosocial conditions that are out of the child's control, that tend to co-occur (Rosenman \& Rodgers, 2004), and that often persist over time (Clark, Caldwell, Power, \& Stansfeld, 2010; Felitti, et al., 1998). ACE represent intrafamilial events or conditions causing chronic stress responses in the child's immediate environment taking 6 dimensions at 7,11 and 16 years: (i) Child in care: child has ever been in public/voluntary care services or foster care. (ii) Physical neglect: child appears undernourished/dirty. Household dysfunction, consisting of four categories each contributing to the score: (iii) Offenders: the child lived in a household where a family member was in prison or on probation or is in contact with probation service; (iv) Parental separation: the child has been separated from their father or mother due to death, divorce, or separation. (v) Mental illness: household has contact with mental health services; family member has mental illness. (vi) Alcohol abuse: family member has alcohol abuse problem (Kelly-Irving, Lepage, Dedieu, Bartley, et al., 2013; Kelly-Irving, Lepage, Dedieu, Lacey, et al., 2013).

The correlation was largely, but not fully explained, by health behaviors, body mass index, and socioeconomic status in adulthood. These results suggest that a biological link between adverse childhood experiences and adult health may be plausible (Barboza Solis, et al., 2015). In this study, the most important pathway linking ACE to $A L$ was the indirect health behaviors path. Health behavior adoption includes a number of processes that have been well described in the literature. The psychological processes suggest that adverse experiences during childhood could be related to health through a number of psychological mechanisms. These may include poor selfregulation, self-efficacy, and self-management
(Bandura, 1991, 2005). Furthermore, it has been suggested that individuals exposed to adversity induced stress could adopt coping mechanisms by obtaining a pharmacological or psychological benefit from tobacco or alcohol use (Anda et al., 2002; S. R. Dube, Anda, Felitti, Edwards, \& Croft, 2002; Shanta R. Dube, et al., 2006). These results suggest an indirect mechanism of embodiment of early psychosocial experiences via health behaviors and material and/or psychosocial circumstances in adulthood. Nevertheless, these factors did not account for the entire effect, suggesting that other mechanisms could be involved and it deserves further research.

\section{CONCLUSIONS AND FUTURE RESEARCH DIRECTIONS}

Current evidence suggests a link between psychosocial stressors during childhood and physiological dysregulation in adulthood, as measured by allostatic load, in favor of the hypothesis of a biological embodiment of early psychosocial exposures over the life course. Experiencing psychosocial adversity during childhood may influence the biological stress systems in development and make them more susceptible to later disease. Adverse childhood experiences appear to influence adult allostatic load increasing the likelihood of low socioeconomic status, high BMI, and a propensity to engage in unhealthy behaviors. This confirms the existence of an accumulation process, a "chain of risk"/pathway model but we cannot rule out a sensitive period effect.

Despite significant progress in the field of early life stress and biological embedding leading to disease, many challenges remain. Future research should improve quantification of early stress (psychological, social and economic). Starting by using quality prospective longitudinal data to reduce recall bias and lack of accuracy in self-reported experiences. Studies should control for early life health experiences, socioeconomic status, educational attainment and lifestyle factors in adulthood. 
Concerning $A L$, there is currently no consensus regarding the construction of a score capable of capturing physiological wear-and-tear. More collection data with biomarkers from children are needed (e.g. primary teeth, hair cortisol). Moreover, the $A \mathrm{~L}$ score remains limited by the pragmatic issues such as variables availability and score composition. Although the concept of $\mathrm{AL}$ is well defined, there is an on-going debate regarding the choice of relevant physiological systems, biomarkers, their interactions (linear relationships), their importance in the chain of physiological stress responses, as well as their measurement, combinations, weighting and the most suitable statistical analysis (Delpierre et al., 2015). Future research requires progress in the biomarkers collection explicitly designed to assess $A L$ at multiple time points in longitudinal large population-representative samples (Beckie, 2012). Comparative studies are needed to better comprehend the age-related, sex/gender-related ethnic-related differences influences on $\mathrm{AL}$ (Beckie, 2012).

Epidemiological research could test other mediators of biological embedding. Epigenetics, neural structure and function, HPA axis and inflammatory processes represent other valuable mediators (Rutter, 2012). Epigenetics in particular is a suitable candidate to explain the environmental influences on genes. The environment itself does not change gene sequences, nevertheless it can regulate gene expression influencing DNA methylation of several genes (Roth \& Sweatt, 2011). Growing evidence suggests that gene activity is highly sensitive to environmental factors as toxins, diet, stress and behavioral influences (Roth \& Sweatt, 2011). A better understanding of these processes can contribute to the conceptualization of more adapted public health interventions at an individual and at a population level with the objective of reducing health inequalities.

\section{REFERENCES}

Anda, R. F., Whitfield, C. L., Felitti, V. J., Chapman, D., Edwards, V. J., Dube, S. R., \& Williamson, D. F. (2002). Adverse, childhood experiences, alcoholic parents, an later risk of alcoholism and depression. Psychiatric Services, 53(8), 1001-1009. doi: 10.1176/appi.ps.53.8.1001

Bailey, D. B., Bruer, J. T., Symons, F. J., \& Lichtman, J. W. (2001). Critical Thinking About Critical Periods. Baltimore: Paul H. Brookes Publishing Co.

Bandura, A. (1991). SOCIAL COGNITIVE THEORY OF SELF-REGULATION. Organizational Behavior and Human Decision Processes, 50(2), 248287. doi: 10.1016/0749-5978(91)90022-I.

Bandura, A. (2005). The primacy of self-regulation in health promotion. Applied Psychology-an International Review-Psychologie AppliqueeRevue Internationale, 54(2), 245-254. doi: 10.1111/j.1464-0597.2005.00208.x.

Barboza Solis, C., Kelly-Irving, M., Fantin, R., Darnaudery, M., Torrisani, J., Lang, T., \& Delpierre, C. (2015). Adverse childhood experiences and physiological wear-and-tear in midlife: Findings from the 1958 British birth cohort. Proceedings of the National Academy of Sciences of the United States of America, 112(7), E738-746. doi: 10.1073/ pnas. 1417325112.

Barker, D. J. P. (2002). Fetal programming of coronary heart disease. Trends in Endocrinology and Metabolism, 13(9), 364-368. doi: Pii s1043-2760(02)00689-610.1016/s10432760(02)00689-6.

Barker, D. J. P. (2007). The origins of the developmental origins theory. Journal of Internal Medicine, 261(5), 412-417. doi: 10.1111/j.1365-2796.2007.01809.x.

Beckie, T. M. (2012). A Systematic Review of Allostatic Load, Health, and Health Disparities. Biological Research for Nursing, 14(4), 311346. doi: 10.1177/1099800412455688. 
Blane, D. (1995). SOCIAL DETERMINANTS OF HEALTH - SOCIOECONOMIC-STATUS, SOCIALCLASS, AND ETHNICITY. American Journal of Public Health, 85(7), 903-905. doi: 10.2105/ ajph.85.7.903.

Blane, D., Netuveli, G., \& Stone, J. (2007). The development of life course epidemiology. Revue D Epidemiologie Et De Sante Publique, 55(1), 31-38. doi: 10.1016/j.respe.2006.12.004.

Boyce, W. T., Sokolowski, M. B., \& Robinson, G. E. (2012). Toward a new biology of social adversity. Proceedings of the National Academy of Sciences of the United States of America, 109, 17143-17148. doi: 10.1073/ pnas.1121264109.

Bruer, J. T. (2001). Critical Periods: An Overview of Behavior and Biology Critical Thinking About Critical Periods (pp. 3-26). Baltimore: Paul H. Brookes Publishing Co.

Carlson, E. D., \& Chamberlain, R. M. (2005). Allostatic load and health disparities: A theoretical orientation. Research in Nursing \& Health, 28(4), 306-315. doi: 10.1002/ nur.20084.

Center on the Developing Child Harvard University. (2015) Retrieved 09/06/, 2015, from http:// developingchild.harvard.edu/key_concepts/ toxic_stress_response/.

Clark, C., Caldwell, T., Power, C., \& Stansfeld, S. A. (2010). Does the Influence of Childhood Adversity on Psychopathology Persist Across the Lifecourse? A 45-Year Prospective Epidemiologic Study. Annals of Epidemiology, 20(5), 385-394. doi: 10.1016/j. annepidem.2010.02.008.

Danese, A., \& McEwen, B. (2012). Adverse childhood experiences, allostasis, allostatic load, and age-related disease. Physiology \& Behavior, 106(1), 29-39. doi: 10.1016/j. physbeh.2011.08.019.

Danese, A., \& Tan, M. (2014). Childhood maltreatment and obesity: systematic review and metaanalysis. [Article]. Molecular Psychiatry, 19(5), 544-554. doi: 10.1038/mp.2013.54.
Delpierre, C., Barboza Solis, C., Torrisani, J., Darnaudery, M., Bartley, M., Blane, D., \& Kelly-Irving, M. (2015). Allostatic Load as a measure of social embodiment: Conceptual and empirical considerations. Longitudinal and Life Course Studies (in press).

Dube, S. R., Anda, R. F., Felitti, V. J., Edwards, V. J., \& Croft, J. B. (2002). Adverse childhood experiences and personal alcohol abuse as an adult. Addictive Behaviors, 27(5), 713-725. doi: 10.1016/s0306-4603(01)00204-0.

Dube, S. R., Miller, J. W., Brown, D. W., Giles, W. H., Felitti, V. J., Dong, M., \& Anda, R. F. (2006). Adverse childhood experiences and the association with ever using alcohol and initiating alcohol use during adolescence. The Journal of adolescent health : official publication of the Society for Adolescent Medicine, 38(4), 444.e441-410. doi: 10.1016/j.jadohealth.2005.06.006.

Egan, M., Tannahill, C., Petticrew, M., \& Thomas, S. (2008). Psychosocial risk factors in home and community settings and their associations with population health and health inequalities: A systematic meta-review. Bmc Public Health, 8. doi: 23910.1186/1471-2458-8-239.

Felitti, V. J. (2002). The relationship of adverse childhood experiences to adult health: Turning gold into lead. Zeitschrift Fur Psychosomatische Medizin Und Psychotherapie, 48(4), 359-369.

Felitti, V. J., Anda, R. F., Nordenberg, D., Williamson, D. F., Spitz, A. M., Edwards, V., ... Marks, J. S. (1998). Relationship of childhood abuse and household dysfunction to many of the leading causes of death in adults - The adverse childhood experiences (ACE) study. American Journal of Preventive Medicine, 14(4), 245258. doi: 10.1016/s0749-3797(98)00017-8.

Ford, E. S., Anda, R. F., Edwards, V. J., Perry, G. S., Zhao, G. X., Li, C.Y., \& Croft, J. B. (2011). Adverse childhood experiences and smoking status in five states. Preventive Medicine, 53(3), 188193. doi: 10.1016/j.ypmed.2011.06.015. 
Galobardes, B., Lynch, J. W., \& Smith, G. D. (2004). Childhood socioeconomic circumstances and cause-specific mortality in adulthood: Systematic review and interpretation. Epidemiologic Reviews, 26, 7-21. doi: 10.1093/expirev/mxh008.

Gunnar, M. R., Brodersen, L., Nachmias, M., Buss, K., \& Rigatuso, J. (1996). Stress reactivity and attachment security. [Article; Proceedings Paper]. Developmental Psychobiology, 29(3), 191-204. doi: 10.1002/ (sici)1098-2302(199604)29:3<191::aiddev1>3.0.co;2-m.

Gustafsson, P. E., San Sebastian, M., Janlert, U., Theorell, T., Westerlund, H., \& Hammarstrom, A. (2014). Life-Course Accumulation of Neighborhood Disadvantage and Allostatic Load: Empirical Integration of Three Social Determinants of Health Frameworks. [Article]. American Journal of Public Health, 104(5), 904-910. doi: 10.2105/ajph.2013.301707.

Hertzman, C. (1999). The biological embedding of early experience and its effects on health in adulthood. In N. E. Adler, M. Marmot, B. McEwen \& J. Stewart (Eds.), Socioeconomic Status and Health in Industrial Nations: Social, Psychological, and Biological Pathways (Vol. 896, pp. 85-95).

Hertzman, C. (2012). Putting the concept of biological embedding in historical perspective. Proceedings of the National Academy of Sciences of the United States of America, 109, 17160-17167. doi: 10.1073/ pnas.1202203109.

Hertzman, C., \& Boyce, T. (2010). How Experience Gets Under the Skin to Create Gradients in Developmental Health. In J. E. Fielding, R. C. Brownson \& L. W. Green (Eds.), Annual Review of Public Health, Vol 31 (Vol. 31, pp. 329-347). Juster, R.-P., McEwen, B. S., \& Lupien, S. J. (2010). Allostatic load biomarkers of chronic stress and impact on health and cognition. Neuroscience and Biobehavioral Reviews, 35(1), 2-16. doi: 10.1016/j.neubiorev.2009.10.002.
Karlamangla, A. S., Singer, B. H., McEwen, B. S., Rowe, J. W., \& Seeman, T. E. (2002). Allostatic load as a predictor of functional decline MacArthur studies of successful aging. Journal of Clinical Epidemiology, 55(7), 696-710. doi: Pii s0895-4356(02)00399-210.1016/s08954356(02)00399-2.

Karlamangla, A. S., Singer, B. H., \& Seeman, T. E. (2006). Reduction in allostatic load in older adults is associated with lower allcause mortality risk: MacArthur studies of successful aging. Psychosomatic Medicine, 68(3), 500-507. doi: 10.1097/01. psy.0000221270.93985.82.

Kelly-Irving, M., Lepage, B., Dedieu, D., Bartley, M., Blane, D., Grosclaude, P., . . . Delpierre, C. (2013). Adverse childhood experiences and premature all-cause mortality. European Journal of Epidemiology, 28(9), 721-734. doi: 10.1007/s10654-013-9832-9.

Kelly-Irving, M., Lepage, B., Dedieu, D., Lacey, R., Cable, N., Bartley, M., ... Delpierre, C. (2013). Childhood adversity as a risk for cancer: findings from the 1958 British birth cohort study. Bmc Public Health, 13. doi: 76710.1186/1471-2458-13-767.

Kelly-Irving, M., Mabile, L., Grosclaude, P., Lang, T., \& Delpierre, C. (2013). The embodiment of adverse childhood experiences and cancer development: potential biological mechanisms and pathways across the life course. International Journal of Public Health, 58(1), 3-11. doi: 10.1007/s00038-012-0370-0.

Koffijberg, H., Adami, J., Buskens, E., \& Palme, M. (2012). Parental education and adult health outcomes: a cohort study examining disease-specific effects of education levels using Swedish nationwide registries across two generations. Longitudinal and Life Course Studies, 3(3), 298 - 311.

Krieger, N. (2005). Embodiment: a conceptual glossary for epidemiology. Journal of Epidemiology and Community Health, 59(5), 350-355. doi: 10.1136/jech.2004.024562. 
Kuh, D., Ben-Shlomo, Y., Lynch, J., Hallqvist, J., \& Power, C. (2003). Life course epidemiology. Journal of Epidemiology and Community Health, 57(10), 778-783. doi: 10.1136/ jech.57.10.778.

Kuh, D., Ben-Shlomo, Y., \& Susser, E. (2004). A Life Course Approach to Chronic Disease Epidemiology (Second ed.). Oxford: Oxford University Press.

Li, L., Power, C., Kelly, S., Kirschbaum, C., \& Hertzman, C. (2007). Life-time socio-economic position and cortisol patterns in mid-life. Psychoneuroendocrinology, 32(7), 824-833. doi: 10.1016/j.psyneuen.2007.05.014.

Lupien, S. J., McEwen, B. S., Gunnar, M. R., \& Heim, C. (2009). Effects of stress throughout the lifespan on the brain, behaviour and cognition. Nature Reviews Neuroscience, 10(6), 434445. doi: 10.1038/nrn2639.

McEwen, B. S. (1998). Stress, adaptation, and disease - Allostasis and allostatic load. In S. M. McCann, J. M. Lipton, E. M. Sternberg, G. P. Chrousos, P. W. Gold \& C. C. Smith (Eds.), Neuroimmunomodulation: Molecular Aspects, Integrative Systems, and Clinical Advances (Vol. 840, pp. 33-44).

McEwen, B. S. (2006). Protective and damaging effects of stress mediators: central role of the brain. Dialogues in clinical neuroscience, 8(4), 367-381.

McEwen, B. S. (2007). Physiology and neurobiology of stress and adaptation: Central role of the brain. Physiological Reviews, 87(3), 873-904. doi: 10.1152/physrev.00041.2006.

McEwen, B. S., \& Seeman, T. (1999). Protective and damaging effects of mediators of stress - Elaborating and testing the concepts of allostasis and allostatic load. In N. E. Adler, M. Marmot, B. McEwen \& J. Stewart (Eds.), Socioeconomic Status and Health in Industrial Nations: Social, Psychological, and Biological Pathways (Vol. 896, pp. 30-47).

McEwen, B. S., \& Wingfield, J. C. (2003). The concept of allostasis in biology and biomedicine. Hormones and Behavior, 43(1), 2-15. doi: 10.1016/s0018-506x(02)00024-7. Miller, G. E., Chen, E., \& Parker, K. J. (2011). Psychological Stress in Childhood and Susceptibility to the Chronic Diseases of Aging: Moving Toward a Model of Behavioral and Biological Mechanisms. Psychological Bulletin, 137(6), 959-997. doi: 10.1037/a0024768.

Oxford English Dictionary. Retrieved 11/06, 2015, from http://www.oed.com/.

Power, C., \& Elliott, J. (2006). Cohort profile: 1958 British Birth Cohort (National Child Development Study). International Journal of Epidemiology, 35(1), 34-41. doi: 10.1093/ije/dyi183.

Power, C., \& Hertzman, C. (1997). Social and biological pathways linking early life and adult disease. British Medical Bulletin, 53(1), 210-221.

Robertson, T., Benzeval, M., Whitley, E., \& Popham, F. (2015). The role of material, psychosocial and behavioral factors in mediating the association between socioeconomic position and allostatic load (measured by cardiovascular, metabolic and inflammatory markers). Brain Behavior and Immunity, 45, 41-49. doi: 10.1016/j. bbi.2014.10.005.

Rosenman, S., \& Rodgers, B. (2004). Childhood adversity in an Australian population. Social Psychiatry and Psychiatric Epidemiology, 39(9), 695-702. doi: 10.1007/s00127-004-0802-0.

Roth, T. L., \& Sweatt, J. D. (2011). Epigenetic mechanisms and environmental shaping of the brain during sensitive periods of development. Journal of Child Psychology and Psychiatry, 52(4), 398-408. doi: 10.1111/j.14697610.2010.02282.x.

Rutter, M. (2012). Achievements and challenges in the biology of environmental effects. Proceedings of the National Academy of Sciences of the United States of America, 109, 17149-17153. doi: 10.1073/pnas.1121258109.

Seeman, T., Epel, E., Gruenewald, T., Karlamangla, A., \& McEwen, B. (2010). Socio-economic differentials in peripheral biology: Cumulative allostatic load. In N. E. Adler \& J. Stewart 
(Eds.), Biology of Disadvantage: Socioeconomic Status and Health (Vol. 1186, pp. 223-239).

Seeman, T., McEwen, B., Rowe, J., \& Singer, B. (2001). Allostatic load as a marker of cumulative biological risk: MacArthur studies of successful aging. Proceedings of the National Academy of Sciences of the United States of America, 98(8), 4770-4775. doi: 10.1073/pnas.081072698.

Seeman, T., Singer, B., Rowe, J., Horwitz, R., \& McEwen, B. (1997). Price of adaptation Allostatic load and its health consequences - MacArthur studies of successful aging. Archives of Internal Medicine, 157(19), 22592268. doi: 10.1001/archinte.157.19.2259.
Shonkoff, J. P., Garner, A. S., Comm Psychosocial Aspects Child, F., Comm Early Childhood Adoption, D., \& Sect Dev Behav, P. (2012). The Lifelong Effects of Early Childhood Adversity and Toxic Stress. Pediatrics, 129(1), E232-E246. doi: 10.1542/peds.2011-2663.

Taylor, S. E., Way, B. M., \& Seeman, T. E. (2011). Early adversity and adult health outcomes. Development and Psychopathology, 23(3), 939954. doi: $10.1017 / \mathrm{s} 0954579411000411$.

Wiesel, T. N., \& Hubel, D. H. (1963). Effects of Visual Deprivation on Morphology and Physiology of Cells in the Cat's Lateral Geniculate Body (Vol.26). 